Article

\title{
Engaging Youth in Climate Resilience Planning with Social Media: Lessons from \#OurChangingClimate
}

\author{
N. Claire Napawan ${ }^{1, *}$, Sheryl-Ann Simpson ${ }^{1}$ and Brett Snyder ${ }^{2}$ \\ ${ }^{1}$ Department of Human Ecology, College of Agricultural and Environmental Sciences, University of California Davis, Davis, \\ CA 95616, USA; E-Mails: ncnapawan@ucdavis.edu (N.C.N), ssimpson@ucdavis.edu (S.-A.S.) \\ 2 Department of Design, University of California Davis, Davis, CA 95616, USA; E-Mail: blsnyder@ucdavis.edu \\ * Corresponding author
}

Submitted: 4 May 2017 | Accepted: 22 August 2017 | Published: 13 October 2017

\begin{abstract}
In light of the socio-ecological complexities associated with climate vulnerability, planning for community resilience will require participatory techniques to engage those most vulnerable. In particular, youth set to inherit the predicted impacts of climate change must be engaged with the processes that determine the future of their built environments. Drawing from existing literature on youth-based participatory planning and climate engagement, this paper presents an alternative process for engaging youth in climate resilience planning by employing digital technology as a tool for youth-based evaluations of existing built environments. Using the pilot project \#OurChangingClimate as a case study, the authors propose a new model for engaging youth with an understanding of their communities and their resilience or vulnerability to climate change. The article details the use of social media and digital narratives as tools for participatory resilience planning and presents some of the preliminary content generated in four pilot youth workshops held from 2015-2017. Lastly, implications of youth-generated content on climate resilience planning are discussed.
\end{abstract}

\section{Keywords}

climate resilience planning; digital narratives; participatory design; social media; youth engagement

\section{Issue}

This article is part of the issue "Social Ecology of Sustainability", edited by Stephen Wheeler (University of California, Davis, USA), Christina Rosan (Temple University, USA) and Bjoern Hagen (Arizona State University, USA).

(C) 2017 by the authors; licensee Cogitatio (Lisbon, Portugal). This article is licensed under a Creative Commons Attribution 4.0 International License (CC BY).

\section{Introduction}

Climate change provides a good example of a complex systems problem for which place-specific case studies and participatory methodologies are particularly apt. (Berkes \& Jolly, 2001, p. 29)

Climate change is a complex socio-ecological problem: vulnerability to its impacts are determined not merely by environmental conditions, but also by a broad range of social conditions (Reid et. al, 2009; Reid \& Huq, 2007). While mitigation efforts are crucial, so too are efforts at adaptation, and in particular, building community resilience to climate impacts. Borrowing from ecological definitions of resilience, community resilience is defined as the ability for a community to respond to change and disruption while still maintaining its general function, structures, form and identity (Allen \& Bryant, 2011; Amundsen, 2012). Like climate change, resilience does not imply steady states and equilibrium, but instead focuses on questions of the qualitative characteristics of a system, its strengths, long-term viability, and ability to learn and adapt (Allen \& Bryant, 2011; Vale, 2014). Specifically, the ability to learn, adapt, and manage change becomes an important aspect of identifying and understanding climate resilience within a community (Folke, 2006; Magis, 2010; Ross \& Berkes, 2014; Tyler \& Moench, 2012). Thus, community resilience to the com- 
plex socio-ecological challenges associated with climate change requires "communication, social equity, and participation to facilitate transformative learning processes" (Paschen \& Ison, 2013, p. 1084). It requires participatory and engaged planning processes (Berkes \& Folke, 1998; Berkes \& Jolly, 2001).

Community-based adaptation planning, which seeks to engage those most vulnerable to climate impacts, is growing in practice in North American cities (Ebi \& Semenza, 2008), with notable examples in more vulnerable communities in the Northwest Territories of Canada (Armitage, 2005; Cohen, 1997), Florida (Frazier, Wood, \& Yarnal, 2010) and California (Garzon et al., 2012; Moser \& Ekstrom, 2011). These participatory approaches allow planners, decision-makers, and stakeholders to effectively address the complex challenges associated with climate change, linking the social with the ecological factors that contribute to vulnerability or resilience within a community. In addition, these engaged efforts give voice to those most vulnerable to climate change (Ross \& Berkes, 2014). In communities throughout North America (and beyond), vulnerability to climate impacts is inequitably distributed, disproportionately impacting communities of color as well as immigrant and low-income communities (Reid et. al, 2009; Reid \& Huq, 2007). Notably, this includes youth set to inherit the long-term and devastating impacts associated with climate change; youth that are more often limited in their opportunity to participate in political discourses on mitigation or adaptation planning. While young people arguably have the most to lose, "their voices are not prominent in the political, media, or cultural discourse on climate change" (Corner et al., 2015, p. 523).

That urban environments are best planned with the participation of youth has become well-established through research and practice (Derr, Chawla, Mintzer, Cushing, \& Van Vliet, 2013; Francis \& Lorenzo, 2002; Hart, 1997). Integrating youth effectively in community-based climate resilience planning is also necessary. Examples of effective youth-led responses to climate-related disasters have been studied in communities within the Philippines, El Salvador, and New Orleans, and reveal the important role of youth participation to support community resiliency efforts (Mitchell, Haynes, Hall, Choong, \& Oven, 2008; Tanner, 2010; Tanner \& Seballos, 2012). These approaches counter the 'vulnerable youth narrative,' and empower young people to play a role in adapting to climate change and responding to related disaster events (Haynes \& Tanner, 2015; Peek, 2008; Tanner et al., 2009). These examples employ youth engagement to build resilience to climate disasters already threatening their communities; they also suggest possibilities for engaging youth in planning for resilience to predicted impacts.

Building from precedent work, this paper presents an alternative process for engaging youth in climate resilience planning by employing digital technology as a tool for youth-based evaluations of existing built environ- ments. Using the pilot project \#OurChangingClimate as a case study, this paper presents an alternative model for engaging youth with an understanding of their communities and its resilience or vulnerability to climate change. It draws from international precedents in youth-based participatory planning and climate engagement work. In particular, it draws from methodologies such as photovoice and digital storytelling to engage youth in seeing, recording, and sharing their own perceptions of their communities. The paper details the use of social media as a tool for participatory resilience planning and presents some of the preliminary content generated in four youth workshops held from 2015-2017. Lastly, implications of youth-generated content on contemporary community resilience planning efforts are discussed.

\section{Background}

\subsection{Youth Perspectives on Climate Change}

Connecting youth to a sense of urgency represents one of the largest hurdles to effectively engaging them in climate resilience planning. According to recent polls from the Yale Program on Climate Change Communication, $70 \%$ of adult Americans believe climate change is happening, and $58 \%$ are worried; however, only $40 \%$ believe it will harm them personally. In contrast, $70 \%$ of adult Americans believe that climate change will harm future generations (Marlon, Howe, Mildenberger, \& Leiserowitz, 2016). This belief of the inevitable, but not immediate, impact of global environmental change is reflected in the timeframes that national and international climate mitigation policies are determined with decarbonization targets focused for 2030, 2040, 2050 or beyond. Climate scientists similarly describe impacts on decadal time scales in ranges from 2020 to 2100, as do regional and local resilience planning. Climate impacts, carbon targets, and adaptation strategies frequently establish a timescale that will play out for a generation of youth that are simultaneously the best positioned to define our societal responses to, while being the most vulnerable to, climate change (Corner et al., 2015). Despite this, current notions of climate change among U.S. youth appear consistent with adult conceptualizations: it is rarely the top priority. Only $9 \%$ of Americans aged 18-34 were worried about climate change, and only $21 \%$ believe that people are currently experiencing harmful effects of climate change (Feldman, Nisbet, Leiserowitz, \& Maibach, 2010). And while youth between $10-25$ years of age tend to have high levels of acceptance of anthropogenic climate change, climate literacy appears to be particularly low. In the United States, only $7 \%$ of youth aged 18-34 accurately identified 2 degrees Celsius as the correct amount of global temperature rise to be dangerous (McSweeney, 2015).

Another barrier to meaningful youth engagement includes the 'psychological distance' of climate change, as perceived by the general public and by youth in the U.S. 
(Spence, Poortinga, Pidgeon, \& Lorenzoni, 2010). The psychological distance of climate change is manifested both geographically and temporally: long time frames of projected impacts, and the physical distance between many Americans and the sites of some of the more catastrophic climate-related events, are often too great to make the issues feel relevant (Gilbert, 2006). Furthermore, international surveys suggest that the general public believe taking action on climate change is primarily the responsibility of governments, whilst simultaneously expressing low levels of trust in them (Corner et al., 2015). Finally, fear tactics that characterize climate change as 'a terrible, immense, and apocalyptic problem' are successful at capturing people's attention, and thus often utilized by popular media as a result; however, such an approach also leaves people feeling hopeless and unable to see their own relationship to the issue (Lorenzoni, Nicholson-Cole, \& Whitmarsh; O'Neill \& NicholsonCole, 2009).

Despite these challenges, there is growing body of literature that suggests new opportunities and alternative approaches for improving youth (and the broader public) perspectives on climate change. In O'Neill and NicholsonCole's study of public responses to climate-related imagery, they noted that communication approaches that “...take account of individuals' personal points of reference (e.g., based on an understanding and appreciation of their values, attitudes, beliefs, local environment, and experiences) are more likely to meaningfully engage individuals with climate change" (2009, p. 375). Ojala's work on perceptions of climate change in Swedish high school students revealed similar results: constructive hope, one that is "future-oriented, positive, and solution-oriented" is more powerful in engaging students than denial-based hope $(2015$, p. 133). This suggests new modes of engaging youth in climate action are needed beyond globallyscaled climate science perspectives or the 'gloom and doom' approach represented in popular media.

\subsection{Youth Participation in Planning}

As mentioned prior, the participation of young people in urban planning processes is well-established as a beneficiary practice to both urban environments and youth development (Derr et al., 2013; Francis \& Lorenzo, 2002; Hart, 1997). Engaging youth in planning processes must extend beyond the traditional and institutionalized means of public participation, as noted by the work of Derr et al.: "[Youth] have sometimes resisted more conventional methods of participation, such as attending public meetings, interviewing and writing" (2013, p. 487). Their review of alternative methods for engaging youth in Boulder, Colorado includes the use of action groups, digital storytelling, child and youth bill of rights, civic area planning, and photovoice. Photovoice in particular proves to be a useful tool for engaging "...on youths' terms, with methods that they find exciting and relevant" (Derr et al., 2013; p. 499). The photovoice technique was first introduced by Wang and Burris (1997), and prompts youth to photograph their environments and to write brief commentaries about their lives and the places they select. "As a practice based in the production of knowledge, photovoice has three main goals: (1) to enable people to record and reflect their community's strengths and concerns, (2) to promote critical dialogue and knowledge about important issues through large and small group discussion of photographs, and (3) to reach policymakers." (Wang \& Burris, 1997, p. 369). Seen as a kind of storytelling, photovoice has been applied to engage diverse individuals and topics, including aging populations' perspectives on public space (Hou, 2005) and youth perspectives on health (Strack, Magill, \& McDonagh, 2004). In Hou's work with elderly immigrants in Seattle, photovoice was shown to "...empower participants to define and address their concerns, and shift the authority and authorship of design and analysis from experts to the participants" (Hou, 2005, p. 1). Digital storytelling allows for the development of longer format narratives than photovoice, using imagery with narration or written text; the roots of this technique lie in community arts and oral history (Meadows, 2003). Both photovoice and digital storytelling methodologies suggest opportunities for integration with emerging digital and social media-tools and techniques that are increasingly popular among American youth.

Participatory methods are also being applied to engage youth specifically with issues related to climate change with efforts to improve climate literacy and action and to limit disaster risks. They employ techniques such as narrative, social media, and filmmaking to connect youth with climate issues and build resilience. Corner and Robert's analysis of climate-related youth narrative workshops in the United Kingdom provides a list of key strategies for successful engagement: (1) Frame messages as a "contemporary concern requiring immediate response"; (2) Identify climate action as necessary to protect "the things they love"; (3) Focus on "social' as well as 'scientific' consensus"; and (4) Employ "trusted messengers," such as peer-to-peer communications (2014, p. 528). Other youth-based climate engagement work conducted in Australia, Europe, and North America supports this framework (Arnold, Cohen, \& Warner; De Vreede, Warner, \& Pitter, 2014; Hickman, 2012; Reinfried, Rottermann, Aeschbacher, \& Huber, 2010), and in particular, the importance of localized, solutions-based approaches with positive messaging (Percy-Smith \& Burns, 2012). The works of Paschen and Ison (2013) and Walker et al. (2012) on climate narrative demonstrate similar opportunities for engagement to provide new knowledge with regard to vulnerability and resilience as experienced by local community members, as does the work of Haynes and Tanner (2015) which explores the role of participatory video as an alternative methodology for community generated digital storytelling that shares youth experiences of climate-related disasters. Collectively, these engagement techniques suggest a powerful opportunity in 
the employment of digital and social media: social media enables the sharing of personal narratives, supports experiential learning, engages with existing online social activity of today's youth, and promotes peer-to-peer interaction (Corner \& Roberts, 2014a, 2014b; Senbel, Ngo, \& Blair, 2014).

\section{Case Study: \#OurChangingClimate}

\#OurChangingClimate is a participatory design project that engages youth in the exploration, documentation, and sharing of the local effects and experiences of climate change. The project aims to make the impacts of climate change more comprehensible on the neighborhood scale, particularly for youth within vulnerable communities and with limited access to political engagement. \#OurChangingClimate addresses the need for local perspectives by utilizing digital tools to establish a community-driven network that (1) Provides participants with the ability to better visualize the direct impacts of climate change within their surrounding landscapes; (2) Creates opportunities to contribute images and narratives to community-generated neighborhood resilience mapping; and, (3) Encourages youth and other community-members to participate in on-going local conversations about climate change resilience. This is consistent with key strategies for youth engagement detailed in the literature review: re-scaling climate conversations to local impacts, re-framing impacts within participant existing concerns, encouraging youth-led engagement, and finally building a sense of capacity to respond to threats (Corner et al., 2015).

The project began as a pilot in collaboration with the Oakland-based community organization, Institute for Sustainable Economic, Education, and Environmental Design (I-SEEED). In the pilot phase, researchers conducted two half-day workshops with youth groups affiliated with I-SEEED in the spring of 2015. The project expanded in 2015 to include alternative workshop formats, integrated with other Northern California and out-of-state community groups (including adult participants), and diversified the tools used for engagement (including analogue options). A summary of workshop formats, locations, dates, and collaborating organizations is listed in Table 1 . This paper will focus specifically on content generated from four youth-based workshops held between 2015 and 2017: the 2-day pilot workshop in Oakland, California; a half-day workshop held in Milwaukee, Wisconsin in collaboration with the National Organization for Minority Architecture Students (NOMAS) as part of the Imagining America National Conference in October 2016; a 10-week workshop held at the University of California, Davis as part of a first-year seminar offered January through March 2017; and a half-day workshop held in Santa Barbara, California as part of the California Higher Education Sustainability Conference (CHESC) in June 2017.

\section{Methodology: Hashtags \& Digital Narratives}

The four workshops from which content is examined in this paper followed a similar format, despite variations in meeting lengths and frequencies. Led by project team members in coordination with non-profit/community collaborators, workshops began with an introduction to the project team and ice-breaker exercises. Facilitators then introduced participants to the localized projected impacts of climate change through regional vulnerability maps, aerial photographs, and street view imagery and engaged participants in an exercise to discuss, challenge, and revise these representations of local built environments (see Figure 1). Following project and participant introductions, youth were then asked to contribute their imagery and brief narratives using their personal social media accounts. Workshop facilitators requested participants to record evidence of vulnerability and resilience in their communities; they encouraged participants to consider social as well as environmental indicators, and to include conditions of interest to them. Nearly all participants engaged regularly with social media, Instagram and Twitter being the primary networks and several using Facebook. The image and descriptive text contributions to social media models the technique of photovoice, with the added benefit of allowing sharing between a much broader network that includes participants' families and peers. It also allowed the project team to meet participants 'where they are' with tools they already engage with and enjoy (Corner et al., 2015; Senbel et al., 2014).

Participants contributed posts for a span of time that varied in length from ninety minutes to six weeks, depending on the duration of the workshop(s). For Oaklandbased workshops, participants met for two half-day workshops and contributed posts from their own communities during the six-week timeframe between each workshop. Posts from the pilot workshop helped develop the preliminary themes that were utilized in subsequent workshops. Scavenger hunt cards were developed for latter workshops to facilitate student observations of their communities and experiences. Themes were printed on 3.5 inch by 5 inch index cards, describing a social or environmental condition; one side described the condition as resilient (white), the other side as vulnerable (magenta), see Figure 2. Blank cards were also provided to encourage the introduction of new themes by participants. Participants in the Milwaukee and Santa Barbara workshops posted for ninety minutes midway through a half-day workshop from sites surrounding University of Wisconsin, Milwaukee and University of California, Santa Barbara campuses. Students participating in the Davis workshop met weekly for two hours during a ten-week period, and contributed posts weekly for the first six weeks of the seminar. Posts from Davis workshops included observations around the University of California, Davis campus and from students' hometowns (which included international locations). 
Table 1. \#OurChangingClimate workshop locations, dates, formats, and collaborating partners.

\begin{tabular}{|c|c|c|c|c|}
\hline $\begin{array}{l}\text { Workshop } \\
\text { Location }\end{array}$ & Date & Format & Participants & Collaborating Partners \\
\hline $\begin{array}{l}\text { Oakland, } \\
\text { California* }\end{array}$ & $\begin{array}{l}\text { March- } \\
\text { May, } \\
2015\end{array}$ & $\begin{array}{l}\text { (2) Half-Day } \\
\text { Workshops }\end{array}$ & $\begin{array}{l}\text { San Francisco Bay Area } \\
\text { youths affiliated with } \\
\text { I-SEEED }\end{array}$ & $\begin{array}{l}\text { Institute for Sustainable Economic, } \\
\text { Educational, and Environmental Design } \\
\text { (I-SEEED) }\end{array}$ \\
\hline $\begin{array}{l}\text { San Francisco, } \\
\text { California }\end{array}$ & $\begin{array}{l}\text { November, } \\
2015\end{array}$ & $\begin{array}{l}\text { Half-Day } \\
\text { Workshop }\end{array}$ & $\begin{array}{l}\text { San Francisco Bay Area } \\
\text { professional and student } \\
\text { environmental designers }\end{array}$ & OpenIDEO \\
\hline $\begin{array}{l}\text { Davis, } \\
\text { California }\end{array}$ & $\begin{array}{l}\text { March } \\
2016\end{array}$ & $\begin{array}{l}\text { Half-Day } \\
\text { Workshop }\end{array}$ & $\begin{array}{l}\text { University of California, } \\
\text { Davis staff }\end{array}$ & $\begin{array}{l}\text { University of California, Davis, Office of } \\
\text { Sustainability and Carbon Neutrality Effort }\end{array}$ \\
\hline $\begin{array}{l}\text { Davis, } \\
\text { California }\end{array}$ & May 2016 & $\begin{array}{l}\text { Half-Day } \\
\text { Workshop }\end{array}$ & $\begin{array}{l}\text { University of California, } \\
\text { Davis faculty }\end{array}$ & $\begin{array}{l}\text { University of California, Davis, Faculty } \\
\text { Climate Working Group }\end{array}$ \\
\hline $\begin{array}{l}\text { San Francisco, } \\
\text { California }\end{array}$ & $\begin{array}{l}\text { September } \\
2016\end{array}$ & $\begin{array}{l}\text { Half-Day } \\
\text { Workshop }\end{array}$ & $\begin{array}{l}\text { San Francisco Bay Area } \\
\text { professional architects }\end{array}$ & $\begin{array}{l}\text { San Francisco Bay Area Chapter of the } \\
\text { American Institute for Architects (AIA) }\end{array}$ \\
\hline $\begin{array}{l}\text { Davis, } \\
\text { California }\end{array}$ & $\begin{array}{l}\text { September- } \\
\text { December } \\
2016\end{array}$ & $\begin{array}{l}\text { (10) 2-Hour } \\
\text { Workshops }\end{array}$ & $\begin{array}{l}\text { University of California, } \\
\text { Davis undergraduate } \\
\text { students }\end{array}$ & $\begin{array}{l}\text { University of California, Davis First Year } \\
\text { Seminar program }\end{array}$ \\
\hline $\begin{array}{l}\text { Milwaukee, } \\
\text { Wisconsin* }\end{array}$ & $\begin{array}{l}\text { October } \\
2016\end{array}$ & $\begin{array}{l}\text { Half-Day } \\
\text { Workshop }\end{array}$ & $\begin{array}{l}\text { Environmental Design } \\
\text { students from University } \\
\text { of Wisconsin, Milwaukee } \\
\text { and University of } \\
\text { California, Davis; } \\
\text { attendants of the } \\
\text { Imagining America Annual } \\
\text { Conference }\end{array}$ & $\begin{array}{l}\text { University of Wisconsin, Milwaukee's } \\
\text { National Organization of Minority } \\
\text { Architecture Students (NOMAS) and } \\
\text { Imagining America }\end{array}$ \\
\hline $\begin{array}{l}\text { Davis, } \\
\text { California* }\end{array}$ & $\begin{array}{l}\text { January- } \\
\text { March } \\
2017\end{array}$ & $\begin{array}{l}\text { (10) 2-Hour } \\
\text { Workshops }\end{array}$ & $\begin{array}{l}\text { University of California, } \\
\text { Davis undergraduate } \\
\text { students }\end{array}$ & $\begin{array}{l}\text { University of California, Davis First Year } \\
\text { Seminar program }\end{array}$ \\
\hline $\begin{array}{l}\text { Santa } \\
\text { Barbara, } \\
\text { California* }\end{array}$ & June 2017 & $\begin{array}{l}\text { Half-Day } \\
\text { Workshop }\end{array}$ & $\begin{array}{l}\text { Youth and adult } \\
\text { attendants of the CHESC } \\
\text { Conference }\end{array}$ & $\begin{array}{l}\text { California Higher Education Sustainability } \\
\text { Conference }\end{array}$ \\
\hline $\begin{array}{l}\text { Plymouth, } \\
\text { United } \\
\text { Kingdom }\end{array}$ & $\begin{array}{l}\text { August } \\
2017\end{array}$ & $\begin{array}{l}\text { Half-Day } \\
\text { Workshop }\end{array}$ & $\begin{array}{l}\text { Sustainable Earth Institute } \\
\text { students and attendants } \\
\text { of the Balance/Unbalance } \\
\text { Conference }\end{array}$ & $\begin{array}{l}\text { University of Plymouth, Sustainable Earth } \\
\text { Institute and the Balance/Unbalance } \\
\text { Conference }\end{array}$ \\
\hline
\end{tabular}

Note: * indicates workshop content inclusion in paper.

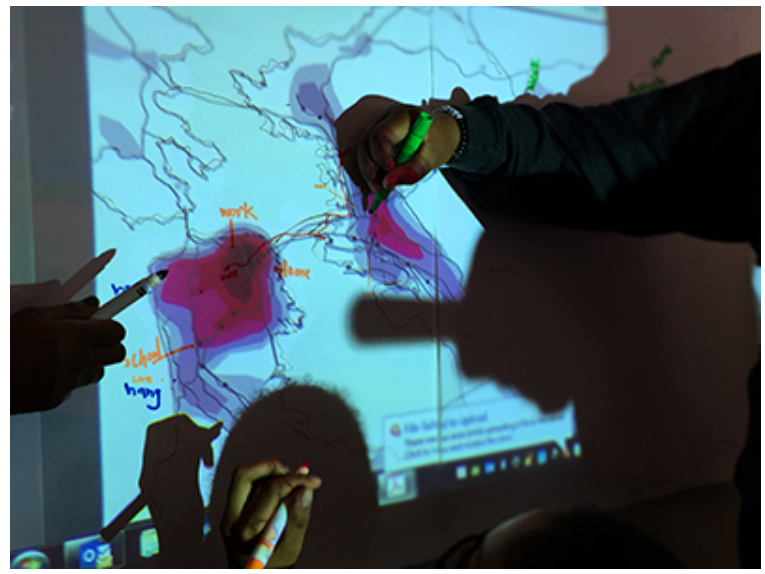

Figure 1. \#OurChangingClimate pilot workshop held in Oakland, California in 2015.
Posts were aggregated using the hashtag 'OurChangingClimate,' and participants often tagged their posts with additional hashtags, such as 'Drought,' 'Community' or other keywords related to their posts. Contributed content was also geo-tagged through the social media posting process, enabling the project team to connect imagery and text with a specific location. When participants and the project team reconvened, content and major themes were discussed. Participants presented their imagery and short narratives, comparing their experiences with fellow participants and, in the case of latter workshops, with prior workshop content. During the latter part of the Oakland and Davis workshops, participants developed a longer narrative based off a theme of their choosing. Youth participants curated from posts aggregated to tell a personal story of their experience of cli- 

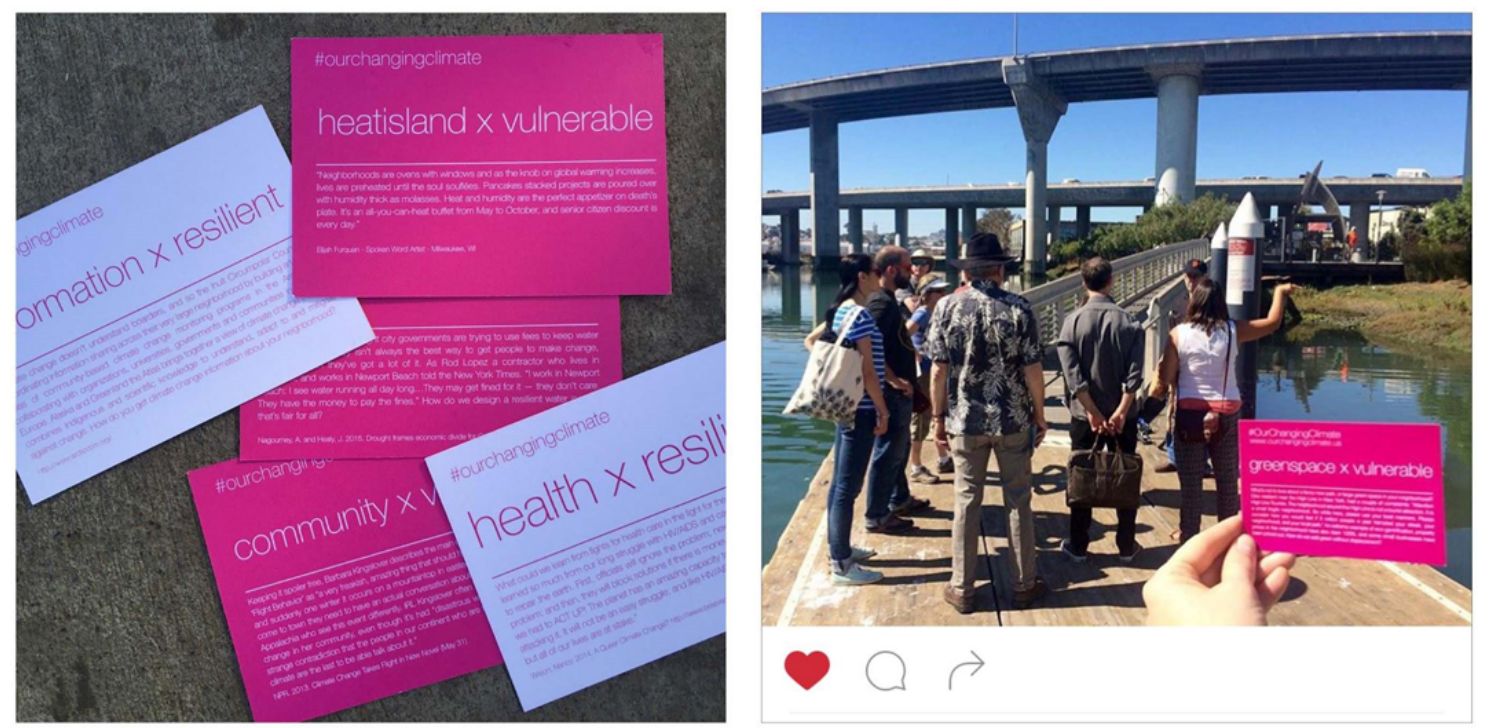

Figure 2. Thematic scavenger hunt cards.

mate change: how they were experiencing vulnerability or resilience to its impacts in their own lives. Limited time prevented Milwaukee and Santa Barbara workshop participants from developing longer narratives. Participants from Oakland and Davis workshops utilized either Storify or Wordpress to create their digital narratives-both free and easy-to-use programs that integrate with existing social media networks.

\section{Youth Content on Climate Change}

Instead of images of polar bears, glaciers, or hurricanes (some of the more popularized imagery associated with climate change), workshop participants contributed more localized and personal images that reflected their own concerns, experiences, and interests. The common themes that arose in youth observations of their communities included: food, transportation, severe weather, community, green space, and health. Each of these themes provides a clear relationship to climate vulnerability or resilience. Many participants also contributed speculative posts, using the prompt 'Whatlf' to project alternative futures of their communities. Lastly, posts that explored the identity of youth participants' communities was also common, often tagged with the hashtag 'TheView.' Below is a list of the four key findings distilled from the youth content. They suggest important techniques for engaging youth in adaptation planning, and new approaches for urban planners to meaningfully plan for community resilience to the socio-ecological challenges of climate change.

\subsection{Food is a Gateway to Youth Engagement with Climate Resilience Planning}

The most common theme in all workshops was food; youth participants were very interested in linking climate change to issues related to personal food choices and habits, food security, sustainable food systems, and management of food waste. This suggests an important opportunity for urban planners to think about food and food systems as an integral part of community resilience planning. There is already increasing interest in connecting food systems planning with urban sustainability efforts in many North American cities (Mendes, Balmer, Kaethler, \& Rhoads, 2008; Napawan, 2014; Pothukuchi \& Kaufman, 2000). Interest in linking climate change to issues related to food suggests a further opportunity to engage youth in community resilience planning. Photographing and talking about food in their social media posts helped many youth connect their own lives to the issues related to climate change: On the one hand, they were able to see how their food choices had an impact on food miles, greenhouse gas emissions, and thus mitigation efforts. Participants were also able to consider how the future impacts of climate change might impact the affordability of some of their favorite foods such as avocados, chocolate, and coffee (see Figure 3).

\subsection{Focus on the Social Dimensions of Climate Vulnerability and Resilience}

Another important trend in posts was the predominant focus on social aspects of climate vulnerability and resilience, as opposed to the environmental aspects. This emerged in the themes such as food insecurity, public health, and an interest in building community (see Figures 4 and 5). Even when exploring environmental conditions, such as green infrastructure or transportation, youth often approached this content through the lens of how green space can build community, or who has access to transportation (Figures 6 and 7). Nearly all longer format digital narratives from the Oakland and Davis workshops focused on social characteristics of resilience or vulnerability within a community. Narratives explored participant interests in food security, public health, envi- 


\section{COGITATIO}

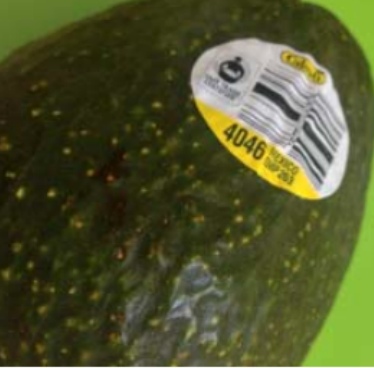

"How far has your produce traveled? \#ourchangingclimate \#mexicotosf \#avocado" via Instagram, Oakland workshop participant

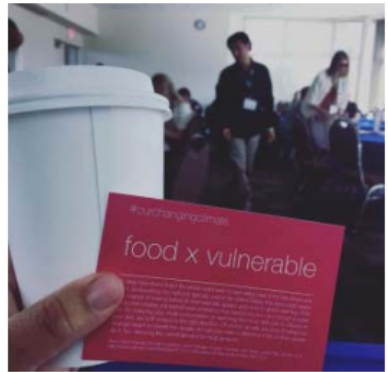

"I'm concerned about \#ourchangingclimate because of its potential impact to my need for caffeine!" via Instagram, Sa Barbara workshop participant

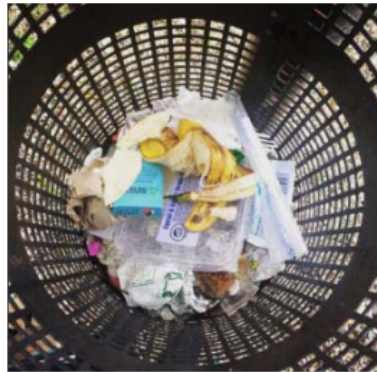

"Foodwaste in the trash bin?! \#ourchangingclimate via Instagram, Milwaukee workshop participant

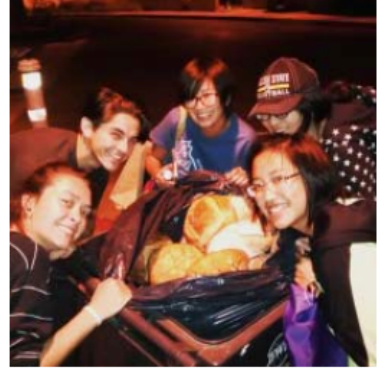

"Village bakery bread makes for a great midnight snack! \#foodwaste \#dumpster diving \#freegan via Instagram, Davis workshop participant

Figure 3. Food-related posts.

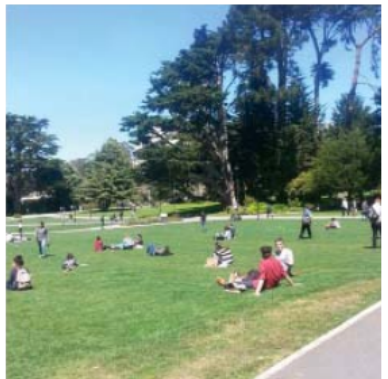

"SFSU. Green space makes opportunity to unite with community, If only, if only... \#ourchangingclimate \#climatechange" via Instagram, Oakland workshop participant

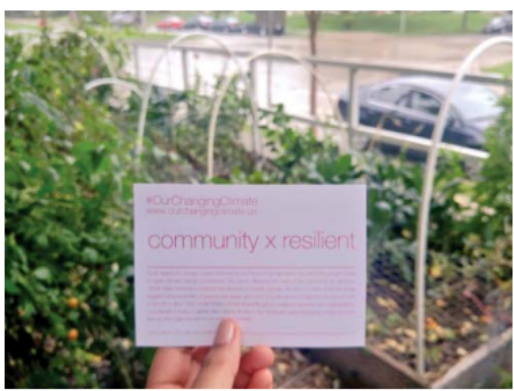

"Elevated public spaces and student gardens help create campus community. \#ourchangingclimate" via Twitter, Milwaukee workshop participant

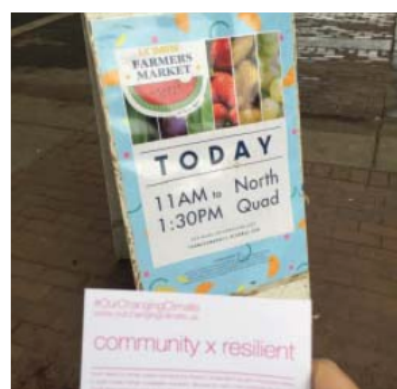

"Davis Farmer's Market builds community. \#ourchangingclimate" via Twitter, Davis workshop participant

Figure 4. Community-related posts.

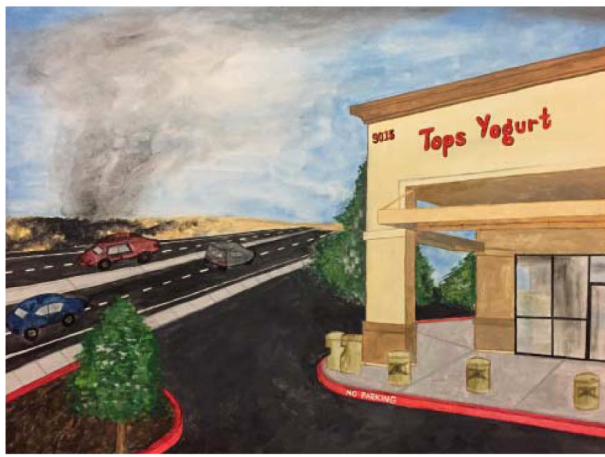

"I live near a field of dead grass that is across the street from my neighborhood. It has caught on fire the last two years... The fire left burnt patches of grass that would eventually fade- not nice to look at. It would create a very smoke atmosphere and smell bad when you step outside. Dangerous for me because I could enconter this scene when I leave the neighborhood or walk home from school." via Wordpress, Davis workshop participant

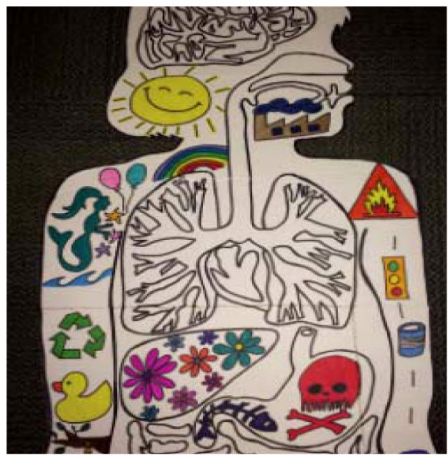

"This is the profile of a little girl and her main organs... The left side of her body is the happy and healthy life. The life this child was to live if humans recycled, took care of the ocean, or cut down less tress so children can have a swing. The right side of her body is the polluted and impure life. A life full of inhaling too much smog from forest fires due to droughts, or not being able to enjoy a sunny day out on the beach." via Wordpress, Davis workshop participant
"Allergies, in general, are increasing throughout the westernized world", Dr. David Rosenstreich, chief of the division of the allergy and immunology at the Albert Einstein College of Medicine and Montefiore Medical Center in New York, told CBS News. "Because of global warming and $\mathrm{CO}_{2}$ levels in the air, they're making more pollen. The pollen seasons tend to begin earlier, last longer and are more severe."

"my allergies are ruining my sleep \#cbsnewsarticle \#allergyseason \#ourchangingclimate" via Instagram, Oakland workshop participant

Figure 5. Health-related posts. 


\section{COGITATIO}

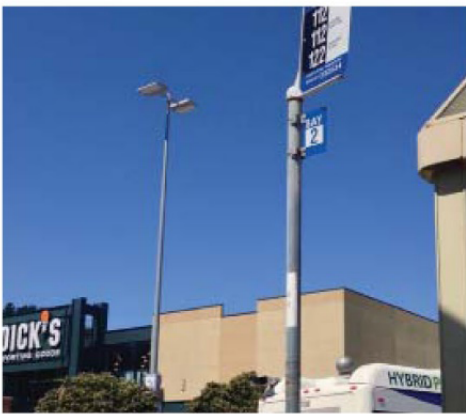

"Waited 20 minutes for the 122 . It came and was full so l'll be waiting another 30 minutes for the next one... \#publictransportation \#busriderlife \#ourchangingclimate" via Instagram, Oakland workshop participant

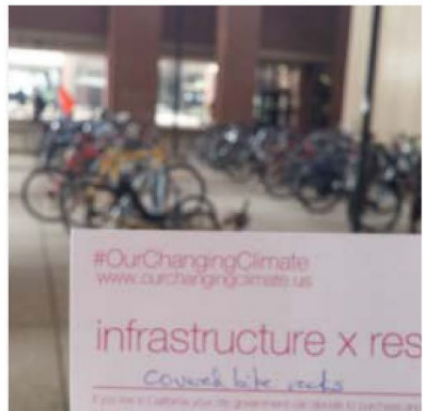

“\#IA2016MKE

\#ourchangingclimate covered bike racks protect resilient transportation" via Twitter, Milwaukee workshop participant

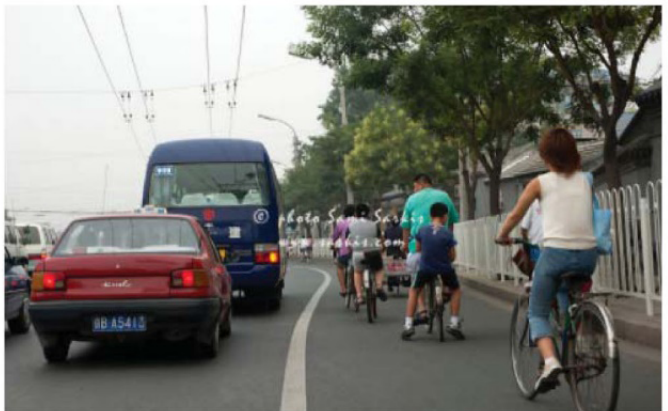

"From my middle school to high school in Beijing, I used to ride bike every day to school. I felt that most streets in Beijing are not friendly to cyclits. Most streets don't have bike path. I usually ride bike among the noisy beep and exhaust of cars. Terrible." via Wordpress, Davis workshop participant

Figure 6. Transportation-related posts.

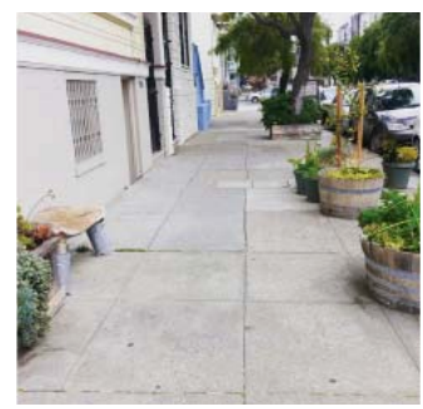

"Lower Haight in San Francisco. My neighbors make the most of the sidewalk! \#ourchangingclimate \#greenspace" via Instagram, Oakland workshop participant

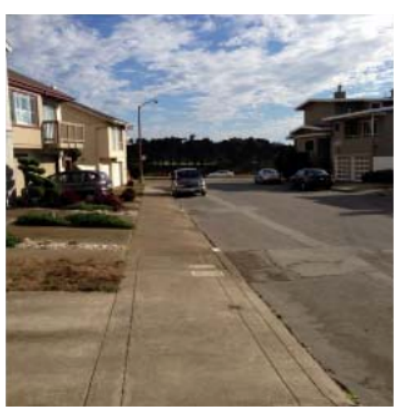

"Lots of impervious surfaces! Neighborhood could use some \#greenspace \#ourchangingclimate" via Instagram, Oakland workshop participant

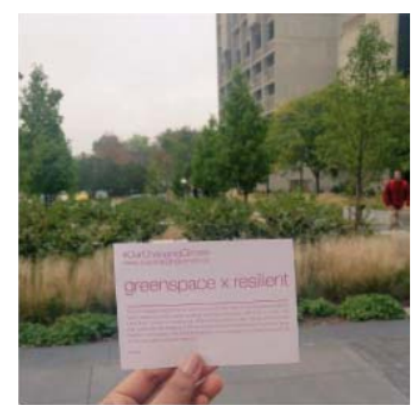

"Campuses are adorned with greenery that often don't exit in low-income spaces. \#ourchangingclimate" via Twitter, Milwaukee workshop participant

Figure 7. Green space-related posts.

ronmental justice, and connecting personal habits (such as diet or commute) to climate change. This finding is consistent with the results of Haynes and Tanner's (2015) participatory video work with youth in the Philippines. Their youth videos reflected the "...social and political root causes of vulnerability...Through this vulnerability emphasis, participants have developed their capacities to reduce risk based not only on physical aspects on the hazard, but also on the human causes of risk that require behavioural and policy change [sic]" (Haynes \& Tanner, 2015 , p. 369). The results of our youth content suggest a similar approach to climate resilience, one with a greater emphasis on addressing the social issues related to the complexities of climate vulnerability.

\subsection{Rescale Environmental Conditions to Local and Regional Scales}

When environmental conditions surfaced in youth content, it tended to be weather-related and reflect the hyper-localized concerns related to climate vulnerabil- ity or resilience; for example, the presence of street trees or pervious pavement and the impact to urban heat island or flooding. Participants also focused on the regional-scaled weather impacts over global-scale: California workshop participants focused on drought, while Wisconsin participants focused on severe storms and extreme temperatures (see Figure 8). Although longer format narratives predominantly focused on social issues, the handful of narratives with an environmental focus also explored localized weather conditions, such as the California Drought or urban heat island impacts within a participant's community. This finding is consistent with many of the key points reviewed in related literature. Again, it suggests rejecting popularized media depictions of climate change that focus primarily on globalscale environmental impacts, and instead rescaling climate resilience planning to address regional, local, and hyper-local concerns. It is also consistent with literature that stresses the importance of locally-scaled adaptation approaches over regional, national, and global scales (Adger, Arnell, \& Tompkins, 2005; Hallegatte \& Corfee- 


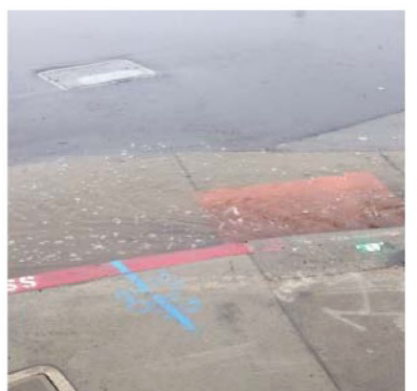

"The rain came down and the in South SF may need to be looked a \#heatisland blazed a many of at. \#flooding \#southsanfrancisco \#suburbs \#ourchangingclimate" via Instagram, Oakland workshop participant

Figure 8. Weather-related posts.

Morlot, 2011) and place-based approaches to resilience efforts (Berkes \& Folke, 1998; Berkes \& Jolly, 2001).

\subsection{Enable Youth to Consider Alternative Futures While Embracing Current Identities}

Speculative and community identity posts were also common, and encompassed the most unexpected themes that developed for the project team. Youth from all workshops felt compelled to suggest new ideas about the places within their community unprompted-proposing new green spaces and improvements to public transportation, or depicting absurd scenarios of projected climate impacts (see Figure 9). This outcome has the clearest implications for urban planning professionals seeking to engage youth in re-imagining new and resilient communities, and reinforces the findings from Derr, et al. on their youth participatory planning workshops: "When youth were invited to reimagine...they became more engaged" $(2013$, p. 500$)$. These posts point to the need to
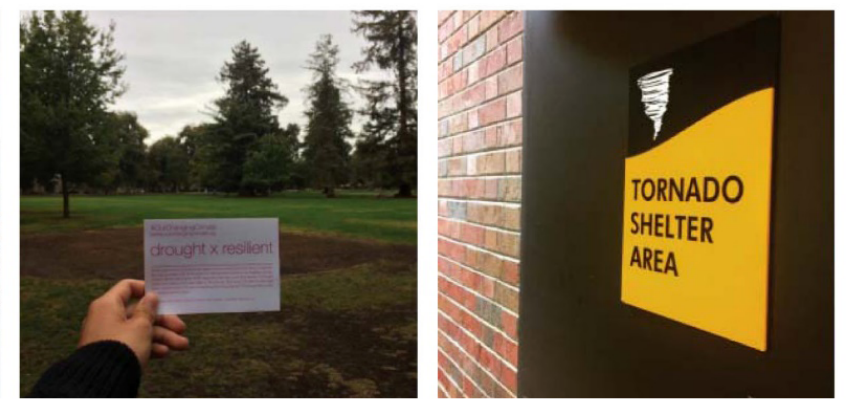

"Trees with deep roots keep water "How far is your shelter from in the soil. Let California dought fade away \#ourchangingclimate" via Twitter, Davis workshop participant extreme weather?

\#ourchangingclimate

\#ia2016mke" via Instagram, Milwaukee workshop participant

engage youth in projecting speculative futures for their community as part of an engaged climate resilient planning process, and the important opportunity that social media can play in supporting this process. Alongside the speculative posts, youth also contributed a range of images that suggested the importance of the visual identity of their communities. Using the tag 'TheView,' many youth participants captured the environmental conditions typically associated with climate vulnerability (shorelines and streetscapes), portraying them as places significant to their community's identity (see Figure 10). This illustrates the ways that youth value existing visual elements within their built environment-regardless of their vulnerability to climate change. It also suggests the importance of maintaining community identity within the resilience planning process. By definition, community resilience includes maintaining its identity, alongside its general structure, functions, and form (Allen \& Bryant, 2011; Amundsen, 2012).

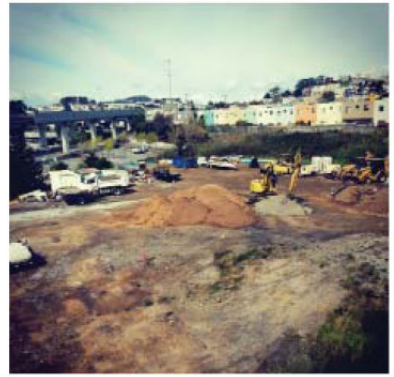

"Daly City construction means community gardens and access to green space right? \#IHopeSo \#climatechange \#ourchangingclimate" via Instagram, Oakland workshop participant

Figure 9. Speculative posts.

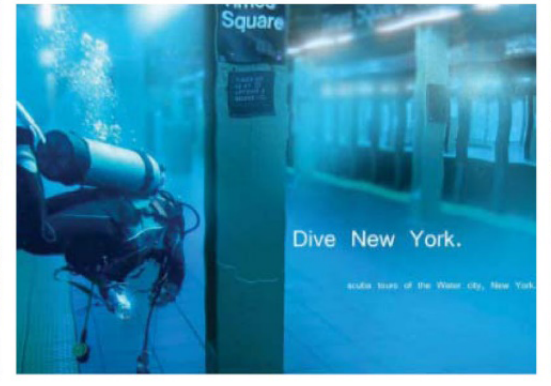

"Water City Scuba Tours, Found in ever major port city by 2050 \#changingclimate" via Twitter, Davis workshop participant

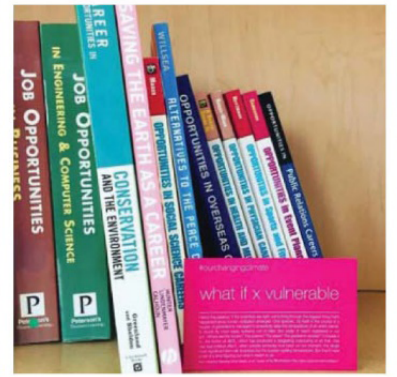

"One day, will people look back at our time in history, and realize we were all foolish not to have a career in taking care of our home? \#ourchangingclimate" via Instagram, Santa Barbara workshop participant

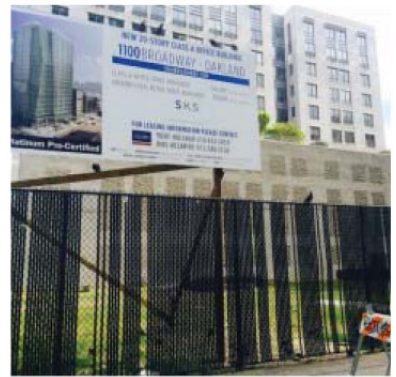

“Hey @Oaklçand, why don't we build a park with this lot? \#ourchangingclimate @sd_opencity" via Twitter, Oakland workshop participant 


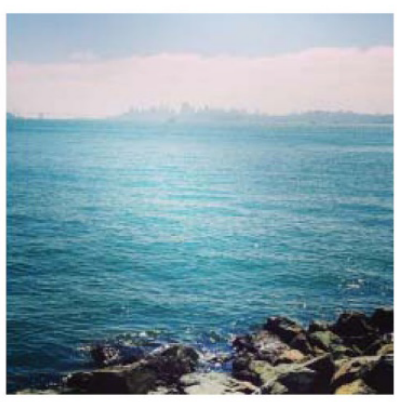

"Damn SF, you're looking fine this morning \#ourchangingclimate" via Instagram, Oakland workshop participant

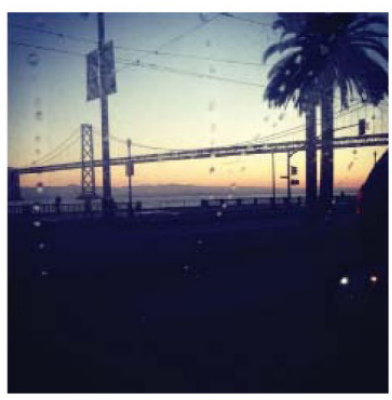

"My view this morning \#ourchangingclimate" via Instagram, Oakland workshop participant
Figure 10. View-related posts.

\section{Conclusions}

Community resilience planning requires defining climate change as a socio-ecological problem and must connect the physical and spatial attributes of community vulnerability with the experiences and perceptions of these characteristics (Berkes \& Folke, 1998; Berkes \& Jolly, 2001). Current adaptation planning approaches often privilege environmental considerations, but precedents in participatory planning methodologies suggest new approaches for integrating community conceptualizations of built environments into the process. In particular, narrative-based approaches offer an alternative approach to adaptation planning: "[It] offers an innovative, holistic approach to a better understanding of socio-ecological systems and the improved, participatory design of local adaptation policies... it can significantly inform public engagement, deliberation and learning strategies-features of systemic adaptive governance" (Paschen \& Ison, 2013, p. 1083). Youth engagement in these strategies has already revealed new paradigms for understanding vulnerability and resilience within a community (Haynes \& Tanner, 2015; Peek, 2008; Tanner et al., 2009), and new digital technologies are diversifying and broadening strategies for that engagement (Corner et al., 2015; Senbel et al., 2014).

\#OurChangingClimate represents an alternative approach to engaging youth in climate resilience planning, exposing the nuanced and personal ways in which youth experience their built environments and understand vulnerability to climate change. As a place-specific case study that employs participatory methodologies, the project exposes the critical connections between the social and environmental conditions of climate change and addresses many of the challenges of sustainability science: "Because of the nonlinearity, complexity, and long time lags, sustainability science will need to use new methodologies, build upon lessons provided by case studies, and work with the local people to produce knowledge" (Berkes \& Jolly, 2001). Preliminary project content

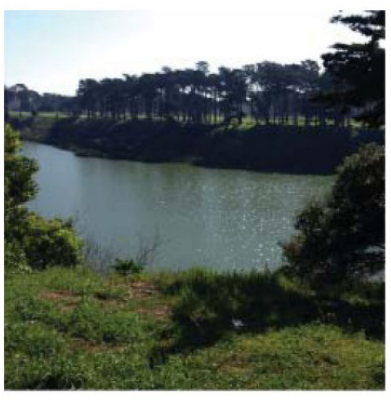

"a reason to put more benches around the lake \#peace \#theview \#ourchangingclimate \#sf" via Instagram, Oakland workshop participant

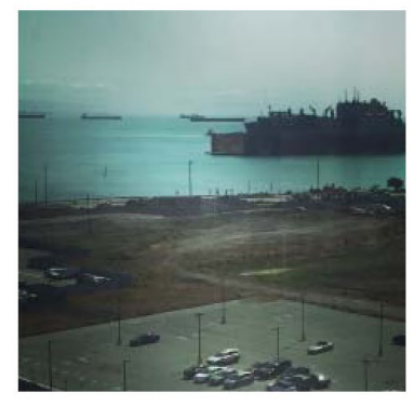

"View from our apartment. \#ourchangingclimate Impervious surface, unused land, shoreline." via Instagram, Oakland workshop participant reveals important implications for community resilience planning efforts. The four main points being: (1) Food is an important gateway for engaging youth in climate resilience planning; (2) Focus on the social dimensions of climate resilience and vulnerability; (3) Rescale environmental conditions of vulnerability and resilience to address the specifics of a location; and (4) Create opportunities for youth to imagine alternative futures, while addressing the identity of their existing communities. Employing these techniques supports youth engagement in adaptation planning efforts. Moreover, engaging youth in a better understanding of their communities and their vulnerabilities, in it of itself, can help build resilience to the socio-ecological complexities of climate change.

\section{Acknowledgments}

We'd like to thank the University of California, Humanities Research Institute; the University of California, Center for Information Technology Research in the Interest of Society; the Hellman Family Fellowship; and the University of California, Davis' Climate Action Champion program for supporting this project.

\section{Conflict of Interests}

The authors declare no conflict of interests.

\section{References}

Adger, W. N., Arnell, N. W., \& Tompkins, E. L. (2005). Successful adaptation to climate change across scales. Global environmental change, 15(2), 77-86. doi:10.1016/j.gloenvcha.2004.12.005

Allan, P., \& Bryant, M. (2011). Resilience as a framework for urbanism and recovery. Journal of Landscape Architecture, 6(2), 34-45. doi:10.1080/18626033. 2011.9723453

Amundsen, H. (2012). Illusions of resilience? An analysis of community responses to change in northern 
Norway. Ecology and Society, 17(4). doi:10.5751/ES05142-170446

Armitage, D. R. (2005). Collaborative environmental assessment in the Northwest Territories, Canada. Environmental Impact Assessment Review, 25(3), 239258. doi:10.1016/j.eiar.2004.06.012

Arnold, H. E., Cohen, F. G., \& Warner, A. (2009). Youth and environmental action: Perspectives of young environmental leaders on their formative influences. The Journal of Environmental Education, 40(3), 2736. doi:10.3200/JOEE.40.3.27-36

Berkes, F., \& Folke, C. (1998). Linking social and ecological systems for resilience and sustainability. In F. Berkes \& C. Folke (Eds.), Linking social and ecological systems: Management practices and social mechanisms for building resilience (pp.1-26). Cambridge: Cambridge University Press.

Berkes, F., \& Jolly, D. (2002). Adapting to climate change: Social-ecological resilience in a Canadian western Arctic community. Conservation Ecology, 5(2), 18.

McSweeney, R. (2015). Global survey: Where in the world is most and least aware of climate change. Climate Brief: Clear on Climate. Retrieved from http://www.carbonbrief.org.

Cohen, S. J. (1997). Scientist-stakeholder collaboration in integrated assessment of climate change: Lessons from a case study of Northwest Canada. Environmental Modeling \& Assessment, 2(4), 281-293. doi:10.1023/A:1019077814917

Corner, A., \& Roberts, O. (2014a). How narrative workshops informed a national climate change campaign. Oxford: Climate Outreach and Information Network.

Corner, A., \& Roberts, O. (2014b). Young voices. Oxford: Climate Outreach and Information Network.

Corner, A., Roberts, O., Chiari, S., Völler, S., Mayrhuber, E. S., Mandl, S., \& Monson, K. (2015). How do young people engage with climate change? The role of knowledge, values, message framing, and trusted communicators. Wiley Interdisciplinary Reviews: Climate Change, 6(5), 523-534. doi:10.1002/wcc.353

De Vreede, C., Warner, A., \& Pitter, R. (2014). Facilitating youth to take sustainability actions: The potential of peer education. The Journal of Environmental Education, 45(1), 37-56. doi:10.1080/ 00958964.2013.805710

Derr, V., Chawla, L., Mintzer, M., Cushing, D. F., \& Van Vliet, W. (2013). A city for all citizens: Integrating children and youth from marginalized populations into city planning. Buildings, 3(3), 482-505. doi:10.3390/buildings3030482

Ebi, K. L., \& Semenza, J. C. (2008). Community-based adaptation to the health impacts of climate change. American Journal of Preventive Medicine, 35(5), 501507. doi:10.1016/j.amepre.2008.08.018

Feldman, L. M., Nisbet, M. C., Leiserowitz, A., \& Maibach, E. (2010). The climate change generation? Survey analysis of the perceptions and beliefs of young Americans. New Haven, CT and Fairfax, VA: Yale
Project on Climate Change and the George Mason University Center for Climate Change Communications. Retrieved from http://climatecommunication. yale.edu/wp-content/uploads/2016/02/2010_03_ The-Climate-Change-Generation.pdf

Folke, C. (2006). Resilience: The emergence of a perspective for social-ecological systems analyses. Global Environmental Change, 16(3), 253-267. doi:10.1016/ j.gloenvcha.2006.04.002

Francis, M., \& Lorenzo, R. (2002). Seven realms of children's participation. Journal of Environmental Psychology, 22(1/2), 157-169. doi:10.1006/ jevp.2001.0248

Frazier, T. G., Wood, N., \& Yarnal, B. (2010). Stakeholder perspectives on land-use strategies for adapting to climate-change-enhanced coastal hazards: Sarasota, Florida. Applied Geography, 30(4), 506-517. doi:10.1016/j.apgeog.2010.05.007

Garzon, C., Cooley, H., Heberger, M., Moore, E., Allen, L., Matalon, E., . . . The Oakland Climate Action Coalition. (2012). Community-based climate adaptation planning: Case study of Oakland, California (Report prepared for the California Energy Commision by the Pacific Institute). Retrieved from http://www. energy.ca.gov/2012publications/CEC-500-2012-038/ CEC-500-2012-038.pdf.

Gilbert, D. (2006, July 2). If only gay sex caused global warming. The Los Angeles Times. Retrieved from http://articles.latimes.com/2006/jul/02/opinion/opgilbert2

Hallegatte, S., \& Corfee-Morlot, J. (2011). Understanding climate change impacts, vulnerability and adaptation at city scale: An introduction. Climatic Change, 104(1), 1-12. doi:10.1007/s10584-010-9981-8

Hart, R. A. (2013). Environmental planning, design, and construction by children. In R. A. Hart (Ed.), Children's participation: The theory and practice of involving young citizens in community development and environmental care (pp. 108-114). London: Earthscan.

Haynes, K., \& Tanner, T. M. (2015). Empowering young people and strengthening resilience: Youthcentred participatory video as a tool for climate change adaptation and disaster risk reduction. Children's Geographies, 13(3), 357-371. doi:10.1080/ 14733285.2013.848599

Hickman, G. M. (2012). Producing ecological citizens, not just green consumers. Engaging youth in environmental action (BA Thesis). Wilfrid Laurier University, Waterloo, Canada.

Hou, J. (2005). Speaking images: A case of photovoice application in community design. Paper presented at Visualizing Change: Association for Community Design Annual Conference, New York.

Lorenzoni, I., Nicholson-Cole, S., \& Whitmarsh, L. (2007). Barriers perceived to engaging with climate change among the UK public and their policy implications. Global Environmental Change, 17(3), 445-459. doi:10.1016/j.gloenvcha.2007.01.004 
Magis, K. (2010). Community resilience: An indicator of social sustainability. Society and Natural Resources, 23(5), 401-416. doi:10.1080/08941920903305674

Marlon, J., Howe, P., Mildenberger, M., \& Leiserowitz, A. (2016). Yale climate opinion maps-U.S. 2016. Yale Program on Climate Change Communication. Retrieved from http://climatecommunication.yale.edu/ visualizations-data/ycom-us-2016

Meadows, D. (2003). Digital storytelling: Research-based practice in new media. Visual Communication, 2(2), 189-193. doi:10.1177/1470357203002002004

Mendes, W., Balmer, K., Kaethler, T., \& Rhoads, A. (2008). Using land inventories to plan for urban agriculture: Experiences from Portland and Vancouver. Journal of the American Planning Association, 74(4), 435-449. doi:10.1080/01944360802354923

Mitchell, T., Haynes, K., Hall, N., Choong, W., \& Oven, K. (2008). The roles of children and youth in communicating disaster risk. Children Youth and Environments, 18(1), 254-279.

Moser, S. C., \& Ekstrom, J. A. (2011). Taking ownership of climate change: Participatory adaptation planning in two local case studies from California. Journal of Environmental Studies and Sciences, 1(1), 63-74. doi:10.1007/s13412-011-0012-5

Napawan, N. C. (2016). Complexity in urban agriculture: The role of landscape typologies in promoting urban agriculture's growth. Journal of Urbanism: International Research on Placemaking and Urban Sustainability, 9(1), 19-38. doi:10.1080/17549175. 2014.950317.

Ojala, M. (2015). Hope in the face of climate change: Associations with environmental engagement and student perceptions of teachers' emotion communication style and future orientation. The Journal of Environmental Education, 46(3), 133-148. doi:10.1080/ 00958964.2015.1021662

O'Neill, S., \& Nicholson-Cole, S. (2009). "Fear won't do it": Promoting positive engagement with climate change through visual and iconic representations. Science Communication, 30(3), 355-379. doi:10.1177/ 1075547008329201

Paschen, J. A., \& Ison, R. (2014). Narrative research in climate change adaptation-Exploring a complementary paradigm for research and governance. Research Policy, 43(6), 1083-1092. doi:10.1016/ j.respol.2013.12.006

Peek, L. (2008). Children and disasters: understanding vulnerability, developing capacities, and promoting resilience-An introduction. Children Youth and Environments, 18(1), 1-29.

Percy-Smith, B., \& Burns, D. (2013). Exploring the role of children and young people as agents of change in sustainable community development. Local Environment, 18(3), 323-339. doi:10.1080/ 13549839.2012.729565

Pothukuchi, K., \& Kaufman, J. L. (2000). The food system: A stranger to the planning field. Journal of the American Planning Association, 66(2), 113-124. doi:10.1080/01944360008976093

Reid, H., Alam, M., Berger, R., Cannon, T., Huq, S., \& Milligan, A. (Eds.). (2009). Community-based adaptation to climate change [Special issue]. Participatory Learning and Action, 60.

Reinfried, S., Rottermann, B., Aeschbacher, U., \& Huber, E. (2010). Changing school students' everyday ideas about global climate change and global warmingA precondition for education for sustainable development. Swiss Journal of Education and Science, 32, 251-273.

Reid, H., \& Huq, S. (2007). Community-based adaptation: A vital approach to the threat climate change poses to the poor (International Institute for Environment and Development Briefing Paper). London: IIED.

Ross, H., \& Berkes, F. (2014). Research approaches for understanding, enhancing, and monitoring community resilience. Society \& Natural Resources, 27(8), 787804. doi:10.1080/08941920.2014.905668

Senbel, M., Ngo, V. D., \& Blair, E. (2014). Social mobilization of climate change: University students conserving energy through multiple pathways for peer engagement. Journal of Environmental Psychology, 38, 84-93. doi:10.1016/j.jenvp.2014.01.001

Spence, A., Poortinga, W., Pidgeon, N., \& Lorenzoni, I. (2010). Public perceptions of energy choices: The influence of beliefs about climate change and the environment. Energy \& Environment, 21(5), 385-407. doi:10.1260/0958-305X.21.5.385

Strack, R. W., Magill, C., \& McDonagh, K. (2004). Engaging youth through photovoice. Health promotion practice, 5(1), 49-58. doi:10.1177/1524839903258015

Tanner, T. (2010). Shifting the narrative: Child-led responses to climate change and disasters in El Salvador and the Philippines. Children \& Society, 24(4), 339-351. doi:10.1111/j.1099-0860.2010.00316.x

Tanner, T., Garcia, M., Lazcano, J., Molina, F., Molina, G., Rodriguez, G., . . Seballos, F. (2009). Children's participation in community-based disaster risk reduction and adaptation to climate change. Participatory Learning and Action, 60(1), 54-64.

Tanner, T., \& Seballos, F. (2012). Action research with children: Lessons from tackling disasters and climate change. IDS Bulletin, 43(3), 59-70. doi:10.1111/j.1759-5436.2012.00323.x

Tyler, S., \& Moench, M. (2012). A framework for urban climate resilience. Climate and Development, 4(4), 311326. doi:10.1080/17565529.2012.745389

Vale, L. J. (2014). The politics of resilient cities: Whose resilience and whose city? Building Research \& Information, 42(2), 191-201. doi:10.1080/09613218. 2014.850602

Walker, M., Whittle, R., Medd, W., Burningham, K., Moran-Ellis, J., \& Tapsell, S. (2012). 'It came up to here': Learning from children's flood narratives. Children's Geographies, 10(2), 135-150. doi:10.1080/ 14733285.2012 .667916 
Wang, C., \& Burris, M. A. (1997). Photovoice: Concept, methodology, and use for participatory needs assess- ment. Health Education \& Behavior, 24(3), 369-387. doi:10.1177/109019819702400309

\section{About the Authors}

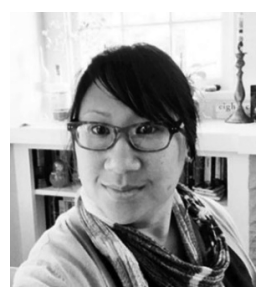

N. Claire Napawan is an Associate Professor of Landscape Architecture and Environmental Design within the Department of Human Ecology at the University of California Davis. Her research focuses on the investigation of urban public landscapes and their role in supporting community resilience.

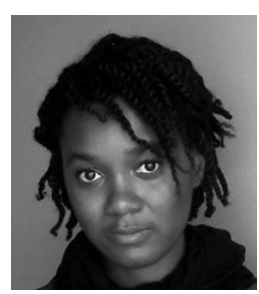

Sheryl-Ann Simpson is an Assistant Professor within the Department of Human Ecology at the University of California Davis. Her research focuses on the relationships between governments and communities.

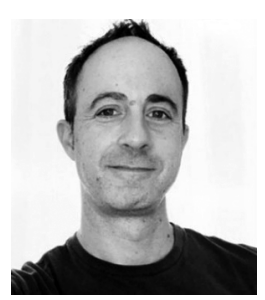

Brett Snyder, AIA is a principal of Cheng+Snyder and an Associate Professor of Design at the University of California, Davis. Snyder works at and researches the intersection of architecture, media, and graphics with a particular interest in urban spaces. 